\title{
LOGISTICAL SUPPORT OF SECONDARY EDUCATION ESTABLISHMENTS IN THE EARLY XXth CENTURY IN KATERYNOSLAV PROVINCE
}

\author{
Alina Papats \\ Postgraduate Student, Mariupol State University, Ukraine \\ e-mail: alinasch48@ukr.net, orcid.org/0000-0002-9001-219X
}

\section{Summary}

The article describes the equipment of secondary education institutions of Katerinoslav region with libraries, textbooks, premises and means. It is revealed that in the early XX century in the territory of Katerinoslav province there were private and state institutions of secondary education, which had external and proper financial support. The main attention is focused on material and technical support of male and female gymnasiums, pro-gymnasiums and real schools. The achievements and problems of the key principles of functioning of these educational cells are also characterized. Almost all secondary education institutions had their own facilities which met sanitary and hygienic requirements of that time. It was found that the material and technical condition of secondary education institutions, such as gymnasiums, pro-gymnasiums and real schools had been improved through government subsidies, private donations and increased tuition fees. Funds were also given for tutorials, educational literature, office supplies and equipment for cabinets and libraries.

Keywords: financing, education institutions, male and female gymnasiums, pro-gymnasiums, real schools, secondary education, cabinets, libraries.

\section{DOI: https://doi.org/10.23856/3824}

Creating favorable educational space for successful learning and development of a full personality is an urgent need of every state. In recent decades, Ukraine has experienced a complex and contradictory process of secondary education reform and its adaptation to the high qualification standards and requirements of European countries. Ensuring the necessary quality, the most efficient and cost-effective scenario for the development of a system of training for teaching specialists is impossible without extensive logistics for both teachers and the school itself. Research and analysis of the development of the secondary education system is an important condition for updating the experience and ideas that have been accumulated during the existence of this system, which will contribute to the revival of the national teacher training school.

The aim of the article is to characterize material and technical support of secondary education institutions, such as gymnasiums, pro-gymnasiums and real schools in Katerynoslav province in the early XX century (the first decade of the 20th century).

Both Soviet and contemporary historians have considered these issues in their works. For example, A. Rozhdestvensky in his work "A brief historical essay of the ten-year existence of the Katerinoslav II Real School named after His Imperial Highness Tsesarevich's heir and Grand Duke Alexei Nikolaevich" (1911) gave a characteristic of Katerinoslav real school, including the question of its logistical equipment. Mariupol historians and regional specialists in their collective work "Mariupol and its surraundings: a look from the XX century" have dealt with the development of secondary education institutions in Mariupol, as well as questions of their financial condition (2008). Many researches were devoted to philanthropists and leading public figures and teachers. For example, modern Ukrainian historians Liakh G., Fatalchuk S. have studied the figure of Hartakhai F., through which the male gymnasium was opened in Mariupol (2005). 
In the Russian Empire, later than in all major states in the late XIX, industrial revolution finished. It took place simultaneously with industrialization, which caused high concentration of production and rapid economic development. But working conditions were very difficult, which led to a working strike movement throughout the empire in the early 20th century. Also the great economic crisis happened that time (1900-1903) and Russian-Japanese War (1904-1905), which was lost by Russia. All these events could not but affect the development of individual provinces, in particular, Katerynoslav. Before the First Russian Revolution, Katerynoslav Province was a rich metallurgical region, which was the part of the "young south". All-Russian events also resonated with Katerynoslav region. The first to strike workshops of Katerininskaya Railway, they were joined by factories and tram workers (Premisler I, 1911). But secondary education continued to develop during this difficult time for Russian Empire. Especially during intensive development of economy during the second stage in 1905-1913. It contributed to the formation of a sufficiently strong financially wealthy section of the population, such as bourgeoisie and merchants. It is thanks to their funds, which they allocated for the development of education, that the state of financial support and educational and material base of the majority of gymnasium institutions has significantly improved. It promoted both creation of new gymnasium institutions and reorganization of previously created ones (Litvin ta in., 2011).

In general, at the beginning of the 20th century there were private and public gymnasiums, pro-gymnasiums and real schools on the territory of Katerynoslav Province. One of the important factors in the successful course of education was the financial situation of the educational institution, which included: external financial support and its own building, premises, manuals, library, etc. The main obstacle to the creation of new secondary education institutions in the province since the second half of the 19th century was the lack of sufficient number of equipped premises. Buildings that were allocated for gymnasium educational institutions were divided into three forms of ownership: local - were provided by the cities where gymnasiums were located, hired - were rented by gymnasiums from private individuals and private - bought or built with the gymnasium funds. Depending on where the financing of the gymnasium came from, it was divided into public (education costs were provided by the public treasury) and private (individuals or certain communities). Private educational institutions were maintained by the funds paid for by education, by the holders of the institutions and by charitable contributions. Public ones were maintained at the expense of the treasury, country council and city administration, also tuition fees, charitable contributions of citizens. The funds were kept and used according to the rules established by the Ministry of National Education (Ustav, 1864).

The management of these institutions was entrusted to councils that worked in each institution: guardianship - for public assistance in their development - and pedagogical - to deal with issues relating to education and training. The Board of Trustees was responsible for the establishment and continuous maintenance of order and improvement of educational institutions, the search for funds for them, the preparation of annual cost estimates and the supervision of the proper use of funds, the determination of tuition fees, etc. (Rozhdestvenskij, 1911).

At the beginning of the XX century, most gymnasiums were housed in hired premises. This allowed the management of educational institutions to spend the main funds on purchase of teaching aids and school equipment. Since the funds allocated for gymnasium institutions from the state treasury and local treasury were very limited and the number of students was insignificant, it was the best option in solving this issue. If there were hired premises, they were usually rented from local residents for long periods. The teachers' councils concluded 
agreements with the latter stipulating the amount of the rent as well as the obligations of the landlords to keep the premises in good condition.

Let us consider the material and technical situation of some secondary educational institutions.

Mariupol female gymnasium opened its doors on September 16, 1876 under the direction of A.A. Henglez (Istoriya najstarishoyi shkoli Mariupolya). For several years the gymnasium was housed in a rented room, and since 1894 it received its own premises of the school of the time. At the beginning of the XX century the gymnasium was an important center of women's education in the province. As of January 1, 1901 the gymnasium consisted of 14 classes. The library consisted of 599 items in 860 volumes, the school library - from 1513 items in 2075 volumes. It was acquired 23 items for the main library and 135 items for the academic library. Libraries did not have their own premises and were located in corridors. The study of Physics had 643 devices, 31 of which were purchased in the reporting year for 127,94 rubles. The Natural Sciences Cabinet had no separate room, it was located in the Physics Cabinet and had 728 units of literature: zoology -441 , botany -59 and mineralogy -228 . In total, the property of the office was estimated at 505,25 rubles. The cost of annual training of one student in 1900 was about 60,30 rubles. It was 0,59 rubles cheaper than in 1899 (Otchet, 1902).

As of 1903, the gymnasium had its own fundamental library of 736 titles in 1,097 volumes and an academic library of 2,113 titles in 2,791 volumes. This year 61 names in 100 volumes for 83,25 rubles were purchased. For the Fundamental Library and 285 titles in 321 volumes for 329,13 rubles. The library had no own premises and was located in corridors. The gymnasium also had a Physics Cabinet, which owed 659 devices, which in the reporting year were purchased for 148,31 rubles. In general, all the room maintenance cost 2829,86 rubles. The Natural Science Cabinet was located in the Physics Cabinet, there was no separate room for it. As of January 1, 1904 there were 792 copies of textbooks, zoology - 488, botany -65 , mineralogy 239. In total, the Cabinet content was 549,95 rubles (Otchet, 1904).

In 1906 the gymnasium was located in its own two-story building, consisted of 24 rooms. As of January 1, 1907 there were 691 items in the Physics Cabinet, 3 of which were purchased that year for 6,5 rubles. The cost of the whole office was 2972,86 rubles. There were 1,050 items in Natural Sciences Cabinet, 3 ones were purchased that year for 6,5 rubles. The cost of the cabinet was 2,972 rubles: 701 in zoology, 110 in botany, 239 in mineralogy. The cost of the Cabinet was 661,2 rubles.

The fundamental library had 811 titles in 1233 volumes, the teaching library was 2520 in 3210 volumes. At this peak, 1381,75 rubles were spent on the fundamental library, on the studying Library - 3045,30 rubles (Otchet, 1901).

\section{Funds for maintenance of Mariupol Mariinskaya female gymnasium}

\begin{tabular}{|c|c|c|c|c|c|}
\hline Year & $\begin{array}{c}\text { From the State } \\
\text { Treasury, } \\
\text { rubles }\end{array}$ & $\begin{array}{c}\text { From city } \\
\text { community, } \\
\text { rubles }\end{array}$ & $\begin{array}{c}\text { Tuition fees, } \\
\text { rubles }\end{array}$ & $\begin{array}{c}\text { From country } \\
\text { council, rubles }\end{array}$ & In total rubles \\
\hline $1900-1901$ & 900 & 9332 & 17147 & - & 27381 \\
\hline $1901-1902$ & 1500 & 8600 & 20189 & 600 & 30889 \\
\hline $1903-1904$ & 2000 & 5656,75 & 26081 & 300 & 34038,12 \\
\hline
\end{tabular}

According to this table, using the example of the Mariupol female gymnasium, we can conclude that during the economic crisis, funds for secondary education were allocated by both state and local governments. 
In the early 20th century, real education was developing and the number of educational institutions was growing. For example, the Katerynoslav Real School was successfully developing and was inaugurated on September 28, 1875. From the first years of its existence the school had certain problems connected with the development of its material base. At first it was in rented houses, and in August 1891 it moved into its own separate two-storied building. The school budget was made up of public funds, tuition fees and private investments. Tuition fees were used to create so-called "special school funds". The tuition fees were set in accordance with the Charter of real schools at the beginning of the school year. At the early XX century, the financial situation of the school improved significantly. For the meteorological station, which was located in the school, a separate premise in the yard was built. The funds for these purposes were allocated by Katerynoslav provincial country councils and annual subsidies for its existence - 1080 rubles a year (Otcet, 1907: 7). It had good fundamental (3868 names in 8295 volumes) and educational (1345 names in 3539 volumes) libraries. The school also had a Physics Cabinet with 537 devices. The Natural Sciences Cabinet had 471 textbooks. In addition, school had Drawing and Chemistry cabinets.

In September 1901 the 2nd real school in Katerynoslav was opened, it was initiated by the acting mayor Volkov P. (Rozhdestvenskij, 1911: 5). Inspector of the state councilor Timoshchenko S.F. was appointed as a director of Katerynoslav First Real school. The school had its own small wooden building, covered with bricks. Since 1904 the school was moved to another large two-story building, because the classrooms were overcrowded. The school had 14 classrooms, a large assembly hall, a Physics Cabinet, two large drawing Cabinets and a gym, a Natural Sciences Cabinet, a Chemistry Cabinet, a fundamental and educational library, etc. (Vsepoddanejshij otchet, 1905: 274). If in the first years of the XX century the fundamental library had 185 volumes, the teaching library, which was created in 1903, had 83 volumes. By 1911 the number of books increased significantly: the fundamental library had 3197 volumes, and the academic library -2215 . If the 1 st real school was maintained primarily at the State expenses, the $2 \mathrm{nd}-$ at the City expenses. Since 1901 tuition fee was 40 rubles per year (Sistematicheskij svod postenovlenij, 1916: 60).

Funds for maintenance of the 2 nd real school in Katerynoslav

\begin{tabular}{|c|c|c|}
\hline Year & Tuition fees, rubles & Municipal Council, rubles \\
\hline 1901 & 2440 & 11005 \\
\hline 1905 & 4996 & 30344 \\
\hline 1910 & 21355 & 31157 \\
\hline
\end{tabular}

According to the table financial situation of the educational institution improved each year, that was reflected in the equipment of the educational cell.

Let's consider the material and technical situation of the institution of male secondary education on the example of the Mariupol male school, which was opened in 1876 at the request of a teacher and public figure Khartakhai F. A., who was appointed as a director of the gymnasium. In 1880 it was renamed to Alexandrviska (Bozhko, 2008: 126).

Since 1899 the Oleksandrivska gymnasium was located in its own premises, on the funds that the city borrowed from the Kharkiv Land Bank and took a ten-year loan from the Ministry of Public Education. There were equipped Physics and Natural Science Cabinet, a Drawing Cabinet, a museum (contained collections of scribbles, coins, jewelry, etc.). There was a good library - fundamental and educational: in 1902 fundamental library contained 5882 titles in 9980 volumes to the sum of 20744,5 rubles. And Academic library contained 2075 titles in 
3211 volumes to the sum of 4004,51 rubles.; in 1903 - 6093 names in 10278 volumes to the sum of 21418,81 rubles, studying - 2,238 names in 3,471 volumes to the sum of 4,302 roubles; $1903-6,093$ names in 10,278 volumes to the sum of 2,1418,32 roubles; 1904 - fundamental 6279 names in 10523 volumes to the sum of 22038 rubles. 55 к., studying - 2,485 names in 3,706 volumes to the sum of 4,548,40 rubles. In general, at the beginning of the 20 th century such funds were spent for development of Olexandrivska gymnasium.

\section{Funds for the maintenance of the Oleksandrivska male gymnasium in Mariupol}

\begin{tabular}{|c|c|c|c|c|c|}
\hline Year & $\begin{array}{c}\text { State Treasury, } \\
\text { rubles }\end{array}$ & $\begin{array}{c}\text { Tuition fees, } \\
\text { rubles }\end{array}$ & $\begin{array}{c}\text { Municipal } \\
\text { Council, rubles }\end{array}$ & $\begin{array}{c}\text { Country } \\
\text { Council }\end{array}$ & $\begin{array}{c}\text { Other, } \\
\text { charitable } \\
\text { contributions }\end{array}$ \\
\hline 1902 & 23375,97 & 22585,92 & 2100 & 1450 & 666,6 \\
\hline 1903 & 24435,47 & 24218,68 & 2150 & 1700 & 1156,77 \\
\hline 1904 & 27348,9 & 24339,62 & 2150 & 1700 & 1581,94 \\
\hline
\end{tabular}

If we compare the funds for the maintenance of secondary educational institutions, we'll see that the amount of money for the development of this link of education has been increasing every year. In general, in gymnasium schools, tuition fees were set individually, so the amount varied from one institution to another.

Thus, it can be concluded that the material and technical support of secondary education institutions in Katerinoslav province at the early 20th century was improved by state subsidies, private donations, and increased tuition fees. Those gymnasiums which managed to attract additional sources of financing (e.g. zemstvo) were in a better financial position. Almost all educational institutions had their own premises, and met sanitary and hygienic requirements of that time. Many funds were allocated for educational literature, equipment of classrooms and office supplies. As a rule, the manuals used by teachers and pupils met the requirements of the time and provided training to clever and talented pupils. Despite the difficult economic and foreign policy situation of the Russian Empire, secondary education institutions in Katerinoslav Region developed and modernized.

\section{References}

Babina O.I. (2000) Stanovlennya ta rozvitok gimnazijnoyi osviti v Ukrayini (v kinci XIX - na pochatku XX stolittya) [Formation and development of gymnasium education in Ukraine (in the late XIX-early XX century) ]: Avtoref. dis... kand. ped. nauk: 13.00.01 / Kiyivskij nacionalnij universitet im. T.G. Shevchenko. Kyiv. [in Ukrainian]

Vsepoddanejshij otchet ministra narodnogo prosvesheniya za 1903 god (1905) [The most submissive report of the Minister of Public Education for 1903]. Sankt-Peterburg. [in Russian] Ekonomichna istoriya Ukrayini : Istoriko-ekonomichne doslidzhennya : 2 t. (2011) [Economic history of Ukraine: Historical and economic research: in 2 volumes] / [red. rada: V. M. Litvin (golova), G. V. Boryak, V. M. Geyec ta in. ; vidp. red. V. A. Smolij ; avt. kol.: T. A. Balabushevich, V. D. Baran, V. K. Baran ta in.] ; NAN Ukrayini, In-t istoriyi Ukrayini. - Kyiv : Nika-Centr. [in Ukrainian]

Istoriya najstarishoyi shkoli Mariupolya. [History of the oldest school in Mariupol] Rezhym dostupu: https://mrpl.city/blogs/view/istoriya-najstarishoi-shkoli-mariupolya [in Ukrainian] Lyah G.R., Fatalchuk S.D.(2005) F.A. Hartahaj - zasnovnik gimnazijnoyi osviti pivdenno-shidnoyi Ukrayini [F. Khartakhai - the founder of gymnasium education of south-eastern 
Ukraine] // Naukova molod: Zbirnik naukovih prac molodih uchenih. Mater. I regionalnoyi nauk. naukovo-prakt. konf. "Vnesok molodih uchenih u rozvitok nauki regionu”. - Lugansk: Znannya. [in Ukrainian]

Mariupol i ego okrestnosti: vzglyad iz XXI veka [Mariupol and its environs: a view from the XXI century] / R. P. Bozhko, T. Yu. Buli, N. N. Gasheenko i dr. (2008) - Izd. 2-e s zmen. I dop. Mariupol: Izd-vo "Renata”. [in Russian]

Otchet Ekaterinoslavskoj gubernskoj zemskoj upravy za 1906 god. (1907). [Report of the Ekaterinoslav Provincial Zemstvo for 1906.] Narodnoe obrazovanie. Ekaterinoslav. [in Russian]

Otchet o sostoyanii Mariupolskoj Aleksandrovskoj gimnazii za 1901 grazhdanskij god (1902) [Report on the state of the Mariupol Alexander Gymnasium for the 1901 civil year]. Mariupol, tip-iya E.I. Goldrina. [in Russian]

Otchet o sostoyanii Mariupolskoj Aleksandrovskoj gimnazii za 1902 grazhdanskij god (1903) [Report on the state of the Mariupol Alexander Gymnasium for the 1902 civil year.]. Mariupol, Tip-iya E. I. Goldrina. [in Russian]

Otchet o sostoyanii Mariupolskoj Aleksandrovskoj gimnazii za 1903 grazhdanskij god (1904). [Report on the state of the Mariupol Alexander Gymnasium for the 1903 civil year.] Mariupol, Tip-iya E. I. Goldrina. [in Russian]

Otchet o sostoyanii Mariupolskoj Aleksandrovskoj gimnazii za 1904 grazhdanskij god.(1904) [Report on the state of the Mariupol Alexander Gymnasium for the 1904 civil year.] Mariupol, Tip-iya E. I. Goldrina. [in Russian]

Otchet o sostoyanii Mariupolskoj Mariinskoj zhenskoj gimnazii za 1900 grazhdanskij god (1901). [Report on the state of the Mariupol Mariinsky Women's Gymnasium for the 1900 civil year]. Mariupol, Tip-iya E. I. Goldrina. [in Russian]

Otchet o sostoyanii Mariupolskoj Mariinskoj zhenskoj gimnazii za 1901 grazhdanskij god. (1902) [Report on the state of the Mariupol Mariinsky Women's Gymnasium for the 1901 civil year]. Mariupol, Tip-iya E. I. Goldrina. [in Russian]

Otchet o sostoyanii Mariupolskoj Mariinskoj zhenskoj gimnazii za 1902 grazhdanskij god. (1903) [Report on the state of the Mariupol Mariinsky Women's Gymnasium for the 1902 civil year] Mariupol, Tip-iya E. I. Goldrina. [in Russian]

Otchet o sostoyanii Mariupolskoj Mariinskoj zhenskoj gimnazii za 1903 grazhdanskij god. (1904) [Report on the state of the Mariupol Mariinsky Women's Gymnasium for the 1903 civil year] Mariupol, Tip-iya E. I. Goldrina. [in Russian]

Revolyuciya 1905-1907 rokiv na Ukrayini : zb. dok. i materialiv. (1949) [Revolution of 1905-1907 in Ukraine: documents and materials] / uporyad. I. Premisler, V. Rudnyev. - Kyiv : Ukr. vid-vo polit. l-ri. [in Ukrainian]

Rozhdestvenskij A. (1911) Kratkij istoricheskij ocherk desyatiletnego sushestvovaniya Ekaterinoslavskogo II imeni Ego imperatorskogo vysochestva gosudarya naslednika cesarevicha $i$ velikogo knyazya Alekseya Nikolaevicha Realnogo uchilisha. [A brief historical sketch of the ten-year existence of Ekaterinoslav II named after His Imperial Highness the Emperor\&apos; heir Tsarevich and Grand Duke Alexei Nikolaevich Real School.] Ekaterinoslav. [in Russian] Sistematicheskij svod postanovlenij Ekaterinoslavskogo gubernskogo zemskogo sobraniya 1866-1913 gg. (1916) [Systematic set of resolutions of the Ekaterinoslav provincial zemstvo assembly of 1866-1913.] / pod red. P.K. Sokolova. Ekaterinoslav. Ch. II, vyp. 2: 1890-1913 gg. [in Russian]

Ustav gimnazij i progimnazij Ministerstva narodnogo prosvesheniya, utverzhdennyj 19.11.1864 g. (1864) [Charter of gymnasiums and progymnasiums of the Ministry of Public Education, approved on November 19, 1864]. SPb.: Izdanie senatskoj tiporafii. [in Russian] 